Faculty of Philosophy,

University of Ss. Cyril and Methodius

Skopje, Macedonia

\title{
BETWEEN EAST AND WEST: \\ EARLY CHRISTIAN BISHOPS FROM THE TERRITORY OF THE REPUBLIC OF MACEDONIA IN HISTORICAL SOURCES
}

\begin{abstract}
The geographical position, strategic role and political significance of Macedonian territory within the prefecture of Illyricum were main factors in the struggle to establish dominant authority over the region in social, cultural and religious aspect. This is most noticeable in the rivalry for supremacy in church law and policy, which also meant influence over every other factors in the empire. The collision between the church and political interests of Rome and Constantinople was thus a central historical characteristic of the Late Antique period and a permanent feature of the Balkan region. Holding primacy over the territory of Illyricum became a major challenge for the clergy of Rome and Constantinople.
\end{abstract}

\section{Introduction}

Christianity, after the last persecutions, had been spreading smoothly, becoming the main factor in the royal politics. In 325, Constantine I took part in the Council of Nicea on which the church-state relationship was established, and where Arianism was proclaimed a heresy. The Nicaea principle of an ecclesiastical hierarchy mirroring the institutions of civil government thus found itself in competition with the political rivalries and inherited traditions of certain bishops and sees, which did not always conform easily to the contemporary map of the Roman Empire. The very principle of identifying the structures of church and state was in itself an invitation to bishops to display the worldliness and ambition of public figures at large. Besides reflecting the political absorption of the church's leaders into the machinery of imperial rewards and punishments, the council of Nicaea had also given formal recognition to an ecclesiastical organization based on that of the Roman state. However varied and irregular the advance of Christianity in different areas of the empire, it had adopted structures which stemmed from the surrounding 'secular' framework. In the early fourth century this process of structural assimilation was far more advanced in the eastern empire (whence almost all of the bishops at Nicaea 
originated), where not only was Christianity more deeply entrenched, but the civic focus of secular administration had the longest history. The traditional primacies of Alexandria and Antioch (the only two sees specifically identified in the canon) were limited to their respective dioceses of Egypt and Oriens. The reason for the restrictive emphasis - besides the specific occasion of Maximus' intrusion - is not far to seek: Alexandria and Antioch now faced competition for supremacy among the churches of the eastern empire from the awakening pretensions of the see of Constantinople. The 381 council identified a new 'seniority of honour' for the bishop of Constantinople, 'next after the bishop of Rome because Constantinople is new Rome' (Can. 3). Such was the secular status of Constantinople as the eastern capital and equal of Rome that by 381 its Christian bishop could not be left behind. The bishops gave no precise definition or scope to his authority, but implied a general superiority over all the churches of the east. The Empire was divided into Illyricum on the West and Thrace in the eastern half. In $343 \mathrm{AD}$, the Arian heresy at the Serdica Assembly deepens the church node between East and West. ${ }^{1}$ With the Edict of Thessalonica (380), Christianity is confirmed as the only recognized religion in the Empire. In 382 East Illyricum was given to the Eastern Empire, including the two provinces of Dacia and Macedonia in the Thracian diocese. Permanent divisions continue after Theodosius' death. Honorius keeps the western, and Arcadius the eastern part.

There is not much confidential information about Christianity on this territory in the pre-Constantine period. More is known about the neighbouring provinces: Thrace, parts of Greece and the southern part of Macedonia; even though it is one area, more precisely beyond Thessaloniki, with the only Christian community in the apostolic age, it seems that throughout the entire Balkan region in the 2nd and 3rd centuries there was no specifically developed Christian culture that would have had influence through its centres and through certain individuals of remarkable significance, as was the case with a number of areas in the east (Asia Minor, Syria, Egypt) and partly to the west (Rome and North Africa).

From the numerous early records of the existence of Christianity in the South Balkan region, one cannot say with certainty that they refer to this area. ${ }^{2}$ The composition of the population is also one of the general conditions for the spread of Christianity; as well as in the Macedonian towns visited by the Apostle Paul (Philippi, Thessalonica and Berroia) also in Stobi there was a Jewish community, which successively worked through two synagogues. ${ }^{3}$

1 Barnard, L.W., "The Council of Serdica, Some Problems Re-assesed", Austin History Center 12, 1980, 46-55

${ }^{2}$ Gasper, Gj., Skopskoprizrenska biskupija kroz stoljeca, Zagreb 1986, 21

${ }^{3}$ Aleksova, B., "The Early Christian Basilicas at Stobi", 33 Corso di cultura sull arte ravennate e byzantina, Ravenna 1986, 53-60 
The early records of the Christian mission in Thessalonica, as well as the surroundings (Achaia, Epirus and Dalmatia) referring to the second half of the 1 st century, ${ }^{4}$ lead to the assumption that in the interior of Macedonia, in the larger cities, which (such as Stobi for example) had a good relationship with the metropolis of Thessalonica, Christianity was known, at least as an idea. For the gradual spread of Christianity in the 2nd and 3rd centuries there are material evidence: inscriptions in Thessalonica (2nd and 3rd century) and Edessa, as well as early Christian tombs. ${ }^{5}$

\section{Between Rome and Constantinople - territory and church relations in Macedonia from Constantine to Justinian}

The region of present-day Macedonia, with the exception of Thessalonica, with which the tradition of virgins-martyrs is related, ${ }^{6}$ is without reliable data on martyrs from the time of the great persecutions, especially missing information about the time of Diocletian. In addition to the tradition of the virgins from Thessaloniki, the legend of St. Erasmus of Lychnidos (or Formia) is the only source for the life and deeds of a martyr from the time of the persecution of the emperor Maximian (285-305) on the territory of the Republic of Macedonia. This legend is preserved in two Latin versions, one older, from the early Middle Ages (6th century?) and one newer, written by pope Gelasius II (1118-1119) between 1078-1088, when he was a monk in Monte Cassino. ${ }^{7}$ Two Greek versions have been preserved: a 11th Century Pascal manuscript, which tells the old Latin legend in the Greek version; as well as the notes contained in the printed collection on the life of the saints, from the Moskopol Collection (1741/1742). Certain testimonies of the existence of Christianity on Macedonian soil date back to 325 after the consecration of the church in Nicaea. Among approximately 300 bishops, three Macedonian bishops from the Macedonian area took part: Alexander of Thessalonica, Budius of Stobi and Dacus of Scupi.

${ }^{4}$ Molthagen, J., "Die ersten Konflikte der Christen in der griechisch - römischen Welt”, Historia 1991, 42-76, especially 49

${ }^{5}$ About the inscriptions see Feissel, D., "Recueil des inscriptions chrétiennes da Macedoine du III au VI ${ }^{\mathrm{e}}$ siècle", BCH Suppl.8, 1983, 113-118. About the tombs see also Микулчић, И., "Раноримски скелетни гробови из Скупа", Старинар Н.С књ. XXIVXXV, 1973-74, Београд 1975

${ }^{6}$ The tradition of the virgin martyrs Agape, Chionia and Irene resembles a legend, but there is also evidence reaching late antiquity. For the cult of the virgin martyrs of Thessalonica in the Western Church, see Quentin, H., Les martyrologes historiques $d u$ moyen âge, Paris 1908, 59, 114, 423, 481

${ }^{7}$ Published by Engels, O., "Die Herasmuspasio Papst Gelasius' II", RQA 51, 1956, 16-33. Later edition Весели, J. М., “Свети Еразмо од Формија, Свети Еразмо Формиски или Охридски?”, Лихнид 6, Охрид 1988, 53-68

${ }^{8}$ Братож, Р., "Ранохристијанската црква во Македонија и нејзините односи со Рим”, Македонско Наследство 13, Скопје 2000, 24 
The issue of Arianism was discussed two decades later at the Serdica Synod (343), which had almost ecumenical significance. In a state of fragmentation of the Christian world of the majority Orthodox and minority Aryan camp, which was created by several bishops from the East with several bishops from the Balkans; at the Council there were a number of bishops from Macedonia: Paregorius a Dardania de Scupis as well as Zosimus a Macedonia de Lignido, then from the areas of ancient Macedonia: Eugenius (Eugenius?) a Macedonia de Dioclecianopoli, Porfirius a Macedonia de Filippis, Aethius a Macedonia de Tessalonica, Jonas a Macedonia de Parthicopoli, Palladius a Macedonia de Dio, Geronicus a Macedonia de Bereu. ${ }^{9}$ All the aforementioned bishops belonged to the Western Orthodox Church, unlike the bishops of the two neighbouring, northern provinces, Dacia Mediterranea and Moesia Prior, which were separated into Aryans and Orthodox. ${ }^{10}$ During the religious wars between the Aryans and the Orthodox, which followed the synod in Serdica, many other synods were held with the participation of many bishops from the Balkans, some of them maybe from Macedonia. Unfortunately, there are data only for the names of the bishops, but no data of their origin, so it remains unknown of those whose name is mentioned only once. From the first synod in Sirmium (351) there are 32 names of Aryan bishops, but for nine of them the origin is unknown. Seven Aryan bishops were changed on the synod in Sirmium (378), but it is not known where they came from. ${ }^{11}$ There is a possibility that one or more of them originated from the Macedonian territory.

It is surprising that in the sources almost a century after the synod in Serdica, the cities of the territory of Macedonia, with the exception of Thessaloniki, rarely appear as the seats of the bishops. This cannot be found as a fact in the list of names of the participants of the Second Ecumenical Council in 381 in Constantinople (where it is safe to say that bishop Acholius of Thessaloniki participated), who together with the Aquileia's council held that same year, represented a great victory over Arianism and heresies that emerge from it. ${ }^{12}$ The Macedonian bishops, as representatives of the pope, played a significant role in the Third Ecumenical Council in Ephesus (431), discussing the problem of Nestorianism; Anatolius from Lychnidos, Sozon from Philippi, Eusebius of Doberos, Maximinus of Serres, Hermogenes from Kasandreia, Luke of Berroia (all from Macedonia Prima ${ }^{13}$ ) and the most prominent among them is Quintillius of Heraclea Lyncestis. ${ }^{14}$ The

9 ibid, 26-27

${ }^{10}$ Bearing in mind that only seven bishops from the province of Macedonia took part in this synod, the absence of bishops from Stobi is confusing.

${ }^{11}$ Братож, 2000, 27

12 ibid, 30

13 ibid, 31. The author thinks that the marking of Macedonia I points to the existence of the province of Macedonia II at this time.

14 ibid, 31 
participation of the Macedonian bishops on the Fourth Ecumenical Council in 451 in Chalkedon where the problem of monophysitism was considered is even more important. Among the 500 participants, at least eight were from the area that we are talking about: Quintilius of Heraclea (with the same role as in Ephesus, 449, ie as the representative of the absent Anastasius of Thessalonica), Nicholas of Stobi and Dardanius of Bargala as the only representatives of Macedonia II; three bishops who were present at Ephesus 449 (Sozon from Philippi, Eusebius of Doberos and Maximinus of Serres), as well as John from Parthicopolis and Honoratus of Thasos (first mentioned here). From the latter period, two more names of bishops are known: Anatolius of Lychnidos (participant of the synod in Ephesus, 449, mentioned in the letter from the bishop of Epirus Nova to the emperor Leo - 457 or a little later ${ }^{15}$ ) and Ursilius of Scupi (mentioned together with two bishops in the letter of the Dardanian bishops from 458 to the same emperor, and as one of the bishops, in the letter-response from Emperor Leo to the bishops of the main provincial cities). ${ }^{16}$

The ecclesiastical-political activity of most bishops has not surpassed the local frames and they usually appear only as signatories of the documents. Among them we rarely meet participants (such as Aetius of Thessaloniki in 343, Flavian of Philippi about 430, and Acholius and Rufus of Thessaloniki) who represented the canonical rules or participated in theological discussions. The Macedonian bishops of that time, without exception, appear as "Western bishops", whose decisions have always been adopted in an Orthodox sense, despite the various movements in the Eastern Christian world. Church relations are even better illustrated by the letters of the Pope, clarifying the Pope's vital interest in this area, certainly increased by the danger of the territory of Macedonia and the goal of Eastern Illyricum to fall under the influence of the bishop of Constantinople (the danger that has arisen since the administrative division of prefecture Illyricum in 379, when the dioceses Macedonia and Dacia belonged to the eastern emperor Theodosius I, ${ }^{17}$ and even more after the council in Constantinople in 381, in which the bishop of Constantinople was elevated second in rank to the Pope according to canon $3^{18}$ ). Pope Damasus reacted as early as 380 , due to changes in relations, with two letters that he sent personally to bishop Acholius of Thessalonica. Damasus' successor, Siricius (384399) in a letter to Achilles's successor Anysius, assigned the Bishop of Thessalonica to appoint bishops in Eastern Illyricum, but with the consent of the Pope. Pope Innocentius I went even further; given the circumstances: Eastern Illyricum after the death of Theodosius was finally

15 Papazoglu, F., Makedonski gradovi u rimsko doba (Les cités macédoniennes a l'epoque romaine), Skopje 1957, 94

${ }^{16}$ Gasper, 1986, 21

${ }^{17}$ Lippold, A., Theodosius der Große und seine Zeit, München 1982, 15

${ }^{18}$ Gasper, 1986, 39-40 
annexed to the Eastern Empire; in order to preserve his interests against the interests of the bishops of Constantinople, he ordered the jurisdiction of the Thessalonian Bishop Rufus over Achaia, Thessalia, Epirus Vetus, Epirus Nova, Cretae, Dacia Mediterraneae, Dacia Ripensis (Coastal), Moesia, Dardania and Preavalitana, ie over the entire Eastern Illyricum plus Preavalitana. ${ }^{19}$ The Thessalonica vicariate gained firm frames in the years 419-423, during Pope Bonifacius I. At a time of violent disputes over the right to the Corinthian episcopal place (419), the Pope confirmed the established administration by Innocentius I in a letter to eight Illyrian bishops present at the Synod of Corinth; repeating it again in the letter to bishop Rufus of Thessaloni$\mathrm{ki}^{20}{ }^{20}$ Following the strengthening of the papal influence in Eastern Illyricum and the displeasure of some, above all Thessalian bishops, in conditions of worsening relations between the Eastern and Western empires, the Eastern Emperor Theodosius II in 421 adopted a law by which the Constantinople bishop was authorized to judge in the resolution of Church disputes in Illyricum; an attempt to undermine the papal power and influence in the area and, finally, the dissolution of the Thessaloniki vicariate.

This practice disturbed the West: Honorius, the ruler of the Western Empire, as a Pope's ally in this matter, successfully mediated with Theodosius II, judging by his diplomatic response. Then the Pope personally sent a letter to bishop Rufus in 422 , as well as to the bishops of Macedonia, Achaia, Thessaly, both Epirus provinces, Praevalitana and Dacia, on the occasion of the resolution of the conflict in Corinth, confirming the creation of the vicariate in Thessalonica. He also confirmed the same with two letters to the bishops of Thessaly, where the resistance was strongest. ${ }^{21}$ The four letters of Pope Sixtus III (432440), referring to relations in Illyricum, contained nothing new about the development of the vicariate; the pope managed to keep it in spite of the threats. During Nestorian wrangling, when Nestorius' adherents (who renounced Rome and demanded allies from Constantinople) appeared among the bishops of Thessaly, Pope Sixtus III supported his supporters, the bishops Flavian of Philippi and Rufus of Thessalonica. The latter summoned the Synod in the fall of 431 to all bishops of the vicariate, to which Nestorianism was rejected. In 435, the Pope rejected the request of Corinthian bishop Perigenes to be equated with the bishop of Thessalonica. In a few letters sent from the Pope to the bishops of Constantinople, Corinth and Illyricum; he confirms the absolute power of the successor of Rufus, Anastasius of Thessalonica. These guarantees were all the more necessary after the adoption of the Theodosius' Code of Law on January 1, 439, containing the disputed law of Emperor Theodosius II, according to which the disputed questi-

\footnotetext{
${ }^{19}$ Братож, 2000, 36

${ }^{20}$ Братож, 2000, 38

${ }^{21}$ ibidem
} 
ons in Illyricum are under the jurisdiction of the bishop of Constantinople.

With the appointment of Pope Leo I (440-461), the vicariate in Thessaloniki has struck a crisis for many reasons. Not only was bishop Anastasius I an inadequate person to discipline the bishops of Illyricum, but the legal order also showed deficiencies. The Vicar powers of the bishops of Thessalonica until then were given to them personally by the Pope, so that Anastasius was only a metropolitan until the death of Sixtus III, and then he had to beg the new Pope to confirm his authority (an act that happened three years later), but the pope Leo reduced his credentials and increased his personal influence. ${ }^{22}$ This can be seen in the Pope's letter to the six metropolitans of Illyricum in response to their letter sent to Rome without the knowledge of the vicar of Thessalonica (which can be taken as evidence of poor hierarchical functioning). One of these metropolitans, Karos, of unknown origin, is probably from Scupi. ${ }^{23}$

Given the circumstances, the absence of Anastasius of Thessalonica at the synod in Ephesus (449) and the Council of Chalcedon (451) is not surprising.

Since the middle of the 5th century, the tension in relations between Macedonia and Rome drops as a result of the political conditions in Italy and the Balkans. In the last two decades of the existence of the Western Roman Empire, anarchy has ruled, but after the occupation of Odoacar in 476, relations with the East became strained again. In the Balkans, some of the provinces; above all Thrace, Messia, Macedonia and Epirus; were affected by the Gothic robberies, in which many Macedonian cities also suffered: Stobi (474), Heraclea (474 and 479) and Lychnidos (479). ${ }^{24}$

The continued enduring efforts of the bishops of Constantinople, with the help of the Emperor, to separate the Eastern Illyricum from Rome, eventually brought result, with the appearance of Acacian schism since 484, and led to an almost complete interruption in the relations between Rome and the vicariate in Thessaloniki. After an unsuccessful attempt to mediate between Rome and Constantinople, taken by the bishops Andrew of Thessalonica and Vetranius of Illyricum; the Macedonian church decided on the church policy of the patriarch of Constantinople. The schism during the reign of Emperor Zenon (476491) and Patriarch Acacius of Constantinople ( $\uparrow 489)$ continued after their death, during the reign of Anastasius I (491-518), who was even greater confederate of monophysitism than his predecessor. ${ }^{25}$

22 Братож, 2000, 42

${ }^{23}$ ibid. The author refers to Pietri, Géographie (fn.15), 26; but the question is open.

${ }^{24}$ Lippold, 1987, 205-215

${ }^{25}$ Charanis, P., Church and State in the Later Roman Empire, The Religious Policy of Anastasius the First, 491-518, Thessaloniki 1974 
The renewal of the Roman influence in East Illyricum came after the modest attempts of Pope Felix III (483-492) that lasted until the arrival of Pope Gelasius I (492-496). He tried to restore the vicariate in Thessalonica (which ceased to exist after Acacian schism); through the correspondence in 493 with the bishops of Dardania and Dalmatia "per fratrem et coepiscopum nostrum Ursicinum" whose bishopric remains unknown to us, but apparently it is a bishop of Dardania. ${ }^{26}$ In the letter he asked the bishops to oppose the "numerous Greek heresies", first condemning the monophysitism, ${ }^{27}$ and then advising them to hold on to the apostolic throne. After this, the Dardanian bishops gathered at the synod in the provincial capital, Scupi, where they told him that they remained faithful to Rome and condemned the teachings of Eutychius, Peter Mongus, Acacius and their supporters. The letter was signed by Dardanian metropolitan John of Scupi and five other bishops, whose episcopal seating is not mentioned. ${ }^{28}$ After several letters in which Pope Gelasius I expressed his satisfaction that the bishops of Dardania and Dalmatia cling to the Apostolic See and its teaching; apparently received a letter from them that upset him, judging by his reply of February $1,496 .{ }^{29}$ It can be concluded that under the influence of eastern propaganda, the bishops began to suspect the correctness of the decision to condemn Acacius. Namely, he was not removed from the rank of the Synod, but directly from the Apostolic See, after being warned in writing for three years not to separate himself from the Catholic and the Apostolic Church. The Pope in the letter talks about the reasons for the absolute power of the Apostolic See, which has the right to condemn and release, even when the Synod was not called; citing several examples of the Eastern Synod condemning and the Pope releasing (Anastasius, Patriarch of Constantinople, John Chrysostom and Flavian, bishops who were sentenced to the so-called "Robber" synod in Ephesus, 449). ${ }^{30}$

We do not know the immediate consequences of the Pope's letter, because there are no reliable historical sources. One of the letters of the Pope Anastasius II, sent in 497, is especially interesting for us, because it is addressed to bishop Laurentius of Lychnidos. The same bishop was called in 516 by Emperor Anastasius I, along with four other bishops of Illyricum, in the royal residence, where he remained seven years before returning to his city (where he died when he was

${ }^{26}$ Gasper, 1986, 52

${ }^{27}$ Братож, 2000, 46. Monophysitism began to spread in 447/448 with Eutychius, a priest from Constantinople; essentially connected with Manichaeism and Marcionism; condemned by Pope Leo and his successors; but although convicted on Council of Chalcedon, it had strong supporters who sought to implement his teachings in the life of the Catholic Church.

28 ibid, 47. Samuhel, Bonosus, Verianus, Faustinus and Ursicinus. On the last one, see supra f.n. 17.

${ }^{29}$ ibid, 50

${ }^{30}$ Братож, 2000, 52 
over 80). ${ }^{31}$ The Acacian schism ended in 34 years (484-518) with the death of Emperor Anastasius I in the summer of 518. As a result, the victory of the Eastern Orthodoxy, especially in Constantinople, was won. Then an order was made to proclaim the new Emperor Justin (from Illyricum), and the Law on the Orthodox Faith (Chalcedonian religion) with threats of severe punishment for those who would not adhere to it. Despite this change, relations with the Apostolic See did not normalize immediately. It was necessary to have extensive correspondence between Pope Hormisdas, Emperor Justin and Crown Prince Justinian in the period from August 518 to March 519, in order to finally reconcile on March 28, 519, by signing the protocol (libelius). Acacius and his supporters, as well as the emperors Zeno and Anastasius, were cursed and excluded from the church; while the Constantinople patriarch recognized the primacy of the Apostolic See. However, the signing of the protocol was not equally welcomed: the bishop of Thessaloniki, Dorotheus, publicly tore down the protocol, expressing disagreement with the Catholic Church's reconciliation; while Theodoritus, the new Lychnidian bishop, greeted pope representatives with enthusiasm and signed the Libelius. ${ }^{32}$

With the advent of Justinian in power (525-565) and the issuing of his Code (the first edition that has not been preserved dates from 529 and the second preserved from 534); which contained also the already forgotten law of Theodosius II of 421, according to which the disputed questions in Illyricum are the responsibility of the Constantinople patriarch; relations with Rome have cooled down again. The next year (535), Justinian founded the Archbishopric Justinian Prima by law, with characteristics of an autocephalous church, as a substitute for the former Sirmium Archbishopric. ${ }^{33}$ From church-organizational point of view, it was assigned to all the Moesian and Dacian areas (Dacia Coastal and Mediterranean, First Moesia, Praevalitana, the rest of Second Panonia, Dardania and Macedonia Secunda, as the only one where the Greek language prevailed). Justinian explained the reasons for the establishment of the archbishopric: when during the devastations of the Huns the transfer of the service from Sirmium to Thessalonica occurred, the church influence of the new centre, Thessalonica, increased, but not according to the dignity of the Thessalonian bishop,

31 ibid, 58

32 Delehay, H., "Les origines du culte des martyrs", Subsidia hagiographica 20, Brüssel 1933, 307.

Lychnidos with Theodoritus, and previously with Lavrentius, was one of those episcopal seats in Illyricum, which, even during Acacian schism, were on the side of the Pope. These excellent relations between the Lychnidos Bishopric and the Apostolic See can be taken into account when interpreting the cult of St. Erasmus on this soil, which probably was already widespread in Rome.

${ }^{33}$ Максимовић, Љ., “Северни Илирик у VI веку (L' Illyricum Septernional au Vie siècle)", Зборник радова Византолошког института 19, 1980, 17-56; especially 26-30. 
but based on the rank of the city in the civilian administration; Justinian presented the highest possible rank to the new archbishopric (from where he originated) as a logical step after the state's expansion to the Danube coast and further. ${ }^{34}$ The church and political reform of Justinian in Illyricum meant an attempt to restore the church organization after a period of chaotic ties, especially in the border provinces along the Danube River, and at the same time, as a pure expression of caesaropapism, it was a heavy blow to the Pope's politics.

The Macedonian area that was previously united with the papal institution of Thessalonica vicariate, with the imperial decision, is divided between the two centres: Thessaloniki (southern and western part) and Justiniana I (central and northern parts).

At the Fifth Ecumenical Council (553) in Constantinople, many bishops from Macedonia participated. A document that Pope Vigilius published the same year, independent of the congressional gatherings, informs us that besides the other signatories, the name of bishop Elias of Thessalonica appears; bishop Benignus Heracleae Pelagoniae advocated during the work of the council instead of the absent previously noted bishop; and as the representative of the absent Archbishop of Justiniana Prima, Benenatus, bishop Phocas of Stobi performed. ${ }^{35}$ The events surrounding the Fifth Ecumenical Council are the last for which there is reliable literary data on this subject.

\section{Conclusion}

The first precisely confirmed data about the existence of church centres in cities located in the territory of Macedonia are persevered in the list of the participants of the First Ecumenical Council in Nicaea; the reference of the bishops from three episcopal centres indicates a substantial degree of church institutional development in the beginning of the $4^{\text {th }}$ century, but judging by the number of bishops and their percentage of participation in the work of the Council as representatives of the regional Church, it seems that the church installations in the region were not highly developed. The names of bishops from church centers in the territory of Macedonia were also mentioned in the acts of the Council held in Serdica in 343-a council which had almost ecumenical significance. Among the hundred and seventy church noblemen who participated in the work of the Council as delegates of the ecumenical Church, nine represented the church institution that functioned in the region of Macedonia. This information indicates the reinforced development of the church institution in our territory, manifested in the enlarged number of episcopal sees as early as in the first half of the 4th century. According to the historical sources, all the mentioned bishops from the region of Macedonia confirmed their or-

\footnotetext{
${ }^{34}$ Братож, 2000, 64

${ }^{35}$ Братож, 2000, 70
} 
thodox orientation and condemned the alternative ideas of Aryanism, contributing to the preservation of the faith in its canonical form during these dramatic times of ideological turmoil and religious turbulence. Although the Acts of the Synod of Serdica gave the bishop of Rome preferences in the institutional government of the Balkan territory and established its dominant status in the sphere of church policy, the end of the century witnessed a drastic change in the balance of religious influence over this region. The influence of the Constantinopolitan church dignitaries was drastically increased simultaneously with their ambitions for the enlargement of their spheres of interest in the territory of the Balkan provinces. Antagonism between Rome and Constantinople became open and public in all of its manifestations during the reign of Theodosius I, including the battle for supremacy between the episcopal representatives of these cities. Due to the growth of the power of the Constantinopolitan clergy and the broadening of their spheres of interest towards the end of the 4th century, the Bishop of Rome was compelled to undertake a number of serious measures and to make use of all available means to secure his sovereignty in the strategically important Balkan region.

These attempts on the part of Roman prelates to secure their supreme position in the Balkans are best confirmed in the preserved official correspondence between the Roman church dignitaries and the episcopal leaders in the territory of Macedonia who no doubt supported the western influence. In this correspondence, one can see the methods and stages of the process of establishing a new institutional form of ecclesiastical rule over Macedonian territory, leading to the appointment of the Vicar of Thessalonica as an official administrative representative of the Roman church in this vital region. Roman domination over the structure of the Vicariate became absolute during the mandate of Pope Leo (440-461) when the role of the vicars was drastically diminished and their privileges were transferred to their officerin-charge in Rome. This is probably the reason for the absence of the Thessalonica bishop from the Second, socalled 'Robber Council' of Ephesus held in 449 and the Council of Chalcedon in 451.

During the second half of the 5th century, communications between the bishop of Thessalonica and the Papacy were completely disrupted, resulting in the decline of Roman church influence over the Balkan territory. With the outbreak of the Acacian schism in 484, relations between Thessalonica and Rome were aborted, while the bishops of Thessalonica recognized the rule of the Patriarchate of Constantinople. The outcome of these disruptive events was that no legal basis existed any more for the further operation of the Vicariate of Thessalonica, and with this loss went the chief means of maintaining Roman ecclesiastical interests in the Balkans. The period of the ecclesiastical schism between Rome and Constantinople initiated by Patriarch Acacius (484-519) can be defined as a time of Constantinople's domination over the church. This was manifested in the territory of Macedonia in 
two equally important ways: in the undertaking of the right to organize and govern the network of episcopal sees and in the dissemination of the ideas and viewpoints of the Constantinopolitan 'dogma', which deviated essentially from the dogma defined at the ecumenical assemblies. For more than three decades, the church institution in the territory of Macedonia was an ally of the Constantinopolitan throne which implemented the church policy of Patriarch Acacius, completely harmonized with the religious viewpoints of Emperor Zeno who was tolerant of Monophysitism. The power of Patriarch Acacius grew even stronger after the death of Zeno in 491 and the coming to the throne of Anastasius, a more ambitious and uncompromising ruler who publicly defended, favoured and protected the Monophysites.

The public support that the Papacy received from the church sees located in the Balkans during the interruption of official relations between Rome and Constantinople is witnessed by the organization of the Synod in Scupi in 494, which sent a note of support to the pontiff in Rome signed by the Dardanian metropolitan Johannes of Scupi. Satisfied with this manifestation of loyalty to the papal throne, the Bishop of Rome responded to his Dardanian colleagues with a letter called Audientes orthodoxam in which he praises them and encourages their positive behavior, as well as their devotion to the true religious belief. With the help of this intense correspondence, a key feature of the relationship between Rome and the Episcopal dignitaries in the territory of Macedonia in the time of Pope Gelasius, a solid continuity was secured in the maintenance of church relations in the hope of a successful restoration of papal interests in this region. Although the bishops in the region invested serious efforts in the accomplishment of the hopes of the Roman church, the chief administrative installation of the papal throne in the Balkans - the Vicariate of Thessalonica - could not be reanimated. The bond between the Thessalonica bishopric and the church authorities in Constantinople remained strong, becoming one of the main sources of dissemination of the ever stronger Monophysite teaching in the Balkans, supported by the state as well as the ecclesiastical government of the Empire.

The impertinence demonstrated by the Illyrian bishops in holding synods and forming a coalition with the Pope instead of being loyal to their own officer-in-chief in Constantinople so infuriated Emperor Anastasius that he punished the 'rebel' archpriests of Nicopolis, Lychnidos, Serdica, Naissus and Pautalia, imprisoning them in the capital of the Empire. This radical act of the Monophysite emperor resulted in church riots in the territory of Illyricum, revealing the inclination of Balkan bishops to the policy of the Roman pontificate. However, until the death of Emperor Anastasius in 518, the territory of the prefecture of Illyricum, including the region of Macedonia, belonged within the sphere of the Constantinopolitan church, open and favorable to the alternative ideas of Monophysitism. With the death of Emperor Anastasius, the loyal supporter of Monophysite ideas and con- 
ceptions in church policy, the period of the first great schism in the ideological context of social life came to an end. The influence and primacy of the Roman pontificate in the eastern parts of the Empire was now restituted. The new emperor, Justin I, who was born in the Balkan territory traditionally sympathetic towards the papal throne, rejected the Henotikon as an unsuccessful doctrinal compromise and accepted the conditions of the Roman church. Justin not only proclaimed his predecessors Zeno and Anastasius to be heretics together with Patriarch Acacius, he also institutionalized the Confession of Chalcedon and established a system of drastic penalties for the disobedient - all with the purpose of destroying Monophysitism. Justin I thus fulfilled the demands of the Pontificate, since good relations with the Roman popes provided a solid basis for his significant political ambitions in the West.

Despite the resistance of some of the clergy, particularly on the part of the Bishop of Thessalonica and his followers, Roman church government was reinstalled in the Balkan territory with reassurance of the development of orthodox belief supported by the papal throne. In this way the administrative power of the Roman church center over the geo-strategically significant Balkan region was restored, while the regional bishops became direct subjects of the papacy. Although orthodoxy was re-imposed as the only officially permitted religious teaching after several decades of schism between Rome and Constantinople, data concerning the discord between Episcopal representatives and the new Byzantine religious policy after 519, as well as certain manifestations in the spheres of spiritual and cultural life, indicate the impossibility of there having been a complete rejection of Monophysite teaching.

Monophysitism remained the burning issue for the church institution during the reign of the greatest emperor of the Late Antique period, Justinian I. Although remarkably talented and highly successful in foreign affairs and state reforms, Justinian was quite helpless in his efforts to cope with alternative religious ideas. Faced with numerous problems related to the territorial restitution of the Empire and well aware of the need to support the Roman church in the pursuit of stable positions in Italy and Northern Africa, Justinian tried constantly to avoid conflicts with the Pontificate. Moreover, peaceful collaboration with the papacy was a guarantee of papal support in the maintenance of complete imperial control over the western territories. For these reasons, Justinian was forced to make concessions to the Roman bishopric, entailing strong support of papal views on dogma and rejection of the Monophysite heresy. Apart from these dynamic problems during Justinian's reign, he also had to face the invasive breakthrough of barbarians in the Balkans where, despite intensive building of fortifications, the barbarian raids proved unstoppable. Justinian thus decided to manage the establishment of normative church jurisdiction over the Balkans with the help of administrative measures that would relieve 
him of concern over the ecclesiastical balance of influence in that region. The solution was found in the form of the establishment of a new church center which would administer circumstances in the politically unstable Balkan region under the direct control of the Emperor. Established amidst the tumult of barbarian invasions, the new Archbishopric of Justiniana Prima was the most representative of these ecclesiastical reforms intended to consolidate circumstances in the prefecture of Illyricum. At the same time, the new church center was a significant attempt to establish a stable equilibrium in the maintenance of religious policy completely independent of the continuous struggle for church supremacy between Rome and Constantinople. With jurisdiction over the Episcopal centers in the territory in which it was established, Justiniana Prima became an expression of the emperor's ambition for the autonomous development of the church institution in the Balkan region. With the establishment of Justiniana Prima, any attempt by the Constantinopolitan patriarch to intervene directly in the maintenance of church policy in the Balkans could be prevented, while the Roman throne received guarantees of the dissemination of orthodox and canonically formulated religious ideas among the believers. In this way Justinian secured stable ecclesiastical control over the Balkan region at the time of political chaos caused by the barbarian invasions.

Within this structure of the situation in the development of church policy under Justinian, the bishops in the territory of Macedonia were under constant pressure from the Roman as well as the Constantinopolitan thrones, although they formally supported the views of their officerin-chief in the newly established archbishopric in the city of Justiniana Prima. Besides the Episcopal representatives of Stobi, Heraclea and Lychnidos whose names are mentioned in the lists of the participants in the First, Second and Third Ecumenical Councils, historical documents contain data on the representatives of other Episcopal sees which geographically belonged to the territory of Macedonia and were under the church jurisdiction of the archbishopric in Justiniana Prima, including Bishop Dardanius of Bargala who participated in the Council of Chalcedon in 451, and Bishop Sabinianus of Zappara whose name is noted in the Acts of the Fifth Ecumenical Council held in Constantinople in 553. In contrast with the precisely situated Episcopal complex in Bargala, discovered during archaeological investigation of the terrain, the location of the bishopric of Zappara remains uncertain. Although Hierocles in his Synecdemus mentioned the city of Zappara as an urban settlement in the territory of the province of Macedonia Secunda, while Procopius of Caesarea in De Aedificiis speaks of a fortified town with a similar name in the vicinity of Pautalia, this episcopal see has not yet been located. 


\section{REFERENCES}

Aleksova, B., "The Early Christian Basilicas at Stobi”, 33 Corso di cultura sull arte ravennate e byzantina, Ravenna 1986

Barnard, L.W., "The Council of Serdica, Some Problems Re-assesed", Austin History Center 12, 1980

Charanis, P., Church and State in the Later Roman Empire, The Religious Policy of Anastasius the First, 491-518, Thessaloniki 1974

Delehay, H., "Les origines du culte des martyrs", Subsidia hagiographica 20, Brüssel 1933

Engels, O., "Die Herasmuspasio Papst Gelasius' II", $R Q A$ 51, 1956

Feissel, D., "Recueil des inscriptions chrétiennes da Macedoine du III ${ }^{\mathrm{e}}$ au VI $\mathrm{VI}^{\mathrm{e}}$ siècle", BCH Suppl.8, 1983

Gasper, Gj., Skopskoprizrenska biskupija kroz stoljeca, Zagreb 1986

Lippold, A., Theodosius der Große und seine Zeit, München 1982

Molthagen, J., "Die ersten Konflikte der Christen in der griechisch - römischen Welt", Historia 1991

Papazoglu, F., Makedonski gradovi u rimsko doba (Les cités macédoniennes a l'epoque romaine), Skopje 1957

Quentin, H., Les martyrologes historiques du moyen âge, Paris 1908

Братож, Р., "Ранохристијанската црква во Македонија и нејзините односи со Рим”, Македонско Наследство 13, Скопје 2000

Весели, Ј. М., “Свети Еразмо од Формија, Свети Еразмо Формиски или Охридски?”, Лихнид 6, Охрид 1988

Максимовић, Љ., “Северни Илирик у VI веку (L' Illyricum Septernional au Vie siècle)", Зборник радова Византолошког института 19, 1980

Микулчић, И., “Раноримски скелетни гробови из Скупа”, Старинар Н.С књ. XXIV-XXV, 1973-74, Београд 1975 
